\title{
Isolation and characterization of microsatellite DNA loci for wild Brassica juncea (Brassicaceae)
}

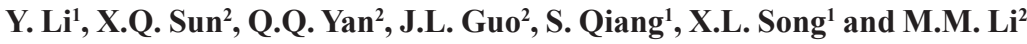 \\ ${ }^{1}$ Weed Research Laboratory, Nanjing Agricultural University, Nanjing, China \\ ${ }^{2}$ Jiangsu Provincial Key Laboratory for Plant Ex Situ Conservation, \\ Institute of Botany, Jiangsu Province and Chinese Academy of Sciences, \\ Nanjing, China \\ Corresponding authors: X.L. Song / M.M. Li \\ E-mail: sx1@njau.edu.cn / limm001@163.com
}

Genet. Mol. Res. 12 (4): 5392-5395 (2013)

Received February 20, 2013

Accepted July 5, 2013

Published November 8, 2013

DOI http://dx.doi.org/10.4238/2013.November.8.1

\begin{abstract}
Wild Brassica juncea is a widespread weed in China with increasingly great impact on the yield of many crops. This study aimed to develop microsatellite markers for assessing the genetic diversity and population genetic structure of $B$. juncea, and to provide basic information for biological and chemical control of the weed. The compound microsatellite marker technique was used to develop markers for investigating population genetics of wild $B$. juncea. Twelve loci were obtained, each of which showed high polymorphisms when tested in two populations in Sichuan and Jiangsu Provinces. The number of alleles per locus ranged from 4 to 27, with an average of 15.2 alleles per locus. The newly developed microsatellite loci will be informative for further investigations of the population genetics and evolutionary patterns of wild $B$. juncea.
\end{abstract}

Key words: Brassicaceae; Microsatellite; Population genetics; Wild Brassica juncea 


\section{INTRODUCTION}

Wild Brassica juncea (L.) Czern. et Coss. (Brassicaceae) is an annual or biennial plant with a wide distribution in central Asia and Russia and has become a malignant naturalized weed throughout China where it infects winter wheat, highland barley, and some other autumn crops (Huangfu et al., 2009). It vigorously competes with crops for water, light, and nutrients, leading to reductions in crop yield (Tu and Qiu, 1989).

Although several studies have been conducted on the genetic diversity of cultivated varieties of B. juncea by using multiple molecular markers (Qiao et al., 1998; Negi et al., 2000; Pradhan et al., 2003), only a few studies have been performed on the genetic diversity of wild B. juncea populations, except for that of Huangfu et al. (2009), which revealed a high level of genetic diversity among different populations of this species by using inter-simple sequence repeat (ISSR) markers. In the present study, we used a recently developed technique (Lian et al., 2006) to isolate microsatellite loci in wild B. juncea for further exploration of its population structure and genetic diversity and to elucidate the migratory pathways of the weed.

\section{MATERIAL AND METHODS}

\section{DNA extraction and microsatellite isolation}

Total genomic DNA was extracted from fresh leaf tissue of wild B. juncea using the modified hexadecyltrimethylammonium bromide (CTAB) method (Doyle, 1991). Voucher specimens for the sampled populations have been deposited in the Herbarium of the Institute of Botany, Jiangsu Province and Chinese Academy of Sciences (NAS). The genomic DNA of one individual from the Nanchong population (designated as NC) of Sichuan Province was digested with the EcoRV restriction enzyme to construct the DNA library. The fragments were then ligated with a specific blunt adaptor (consisting of the upper: 5'-GTA ATA CGA CTC ACT ATA GGG CAC GCG TGG TCG ACG GCC CGG GCT GGT-3' and the lower, with the 3'-end capped with an amino residue: 5'-ACC AGC CC-3') by T4 DNA ligase (Takara). Subsequently, the fragments were polymerase chain reaction (PCR)-amplified from the EcoRV DNA library using the compound SSR primer $(\mathrm{AC})_{6}(\mathrm{AG})_{5}$ or $(\mathrm{TC})_{6}(\mathrm{AC})_{5}$ and an adaptor $\mathrm{AP}_{2}\left(5^{\prime}-\mathrm{CTA}\right.$ TAG GGC ACG CGT GGT- 3 '). Each $50 \mu \mathrm{L}$ PCR contained 2.5-5 ng genomic DNA, 1X PCR buffer with $\mathrm{MgCl}_{2}, 0.2$ $\mathrm{mM}$ of each dNTP, $0.5 \mathrm{U}$ Ex Taq polymerase (Takara), and $0.5 \mathrm{mM}$ each compound SSR primer and $\mathrm{AP}_{2}$. The PCR amplification conditions were as follows: one cycle each of 9 min at $94^{\circ} \mathrm{C}, 30 \mathrm{~s}$ at $62^{\circ} \mathrm{C}$, and $1 \mathrm{~min}$ at $72^{\circ} \mathrm{C} ; 5$ cycles each of $30 \mathrm{~s}$ at $94^{\circ} \mathrm{C}, 30 \mathrm{~s}$ at $62^{\circ} \mathrm{C}$, and $1 \mathrm{~min}$ at $72^{\circ} \mathrm{C} ; 35$ cycles each of $30 \mathrm{~s}$ at $94^{\circ} \mathrm{C}, 30 \mathrm{~s}$ at $60^{\circ} \mathrm{C}, 1 \mathrm{~min}$ at $72^{\circ} \mathrm{C}$; and a final cycle of $30 \mathrm{~s}$ at $94^{\circ} \mathrm{C}, 30 \mathrm{~s}$ at $60^{\circ} \mathrm{C}$, and $9 \mathrm{~min}$ at $72^{\circ} \mathrm{C}$. The products were purified using a DNA clean-up kit (Axygen) and transformed into competent cells (DH5 $\alpha$, Takara) after ligating with the pMD 19-T vector (Takara). A single clone was checked using M13-47/ RV-M primers. Positive clones were obtained and sequenced on an ABI Prism 3730 automated DNA sequencer (Applied Biosystems, Foster City, CA, USA). Specific primers were designed based on sequences flanking the compound SSR primers using Primer Premier 5.0 (Clarke and Gorley, 2001). 


\section{Polymorphisms evaluation}

The designed primers were used to amplify the SSR loci from 40 individuals of wild B. juncea from populations NC and Jiangpu of Jiangsu Province (JP), and their levels of polymorphism were evaluated. The compound SSR primers were labeled with the fluorescent dye 6-FAM or HEX. The amplified products were analyzed by fluorescence capillary electrophoresis, and the data were compiled and scored using GeneMaker 1.95 (Soft-Genetics, State College, PA, USA). The number of alleles $\left(N_{A}\right)$, observed $\left(H_{\mathrm{O}}\right)$ and expected $\left(H_{\mathrm{E}}\right)$ heterozygosities, and polymorphism information content (PIC) were analyzed using Cervus (Kalinowski et al., 2007). Genepop (http://genepop.curtin.edu. $\mathrm{au} /$ ) was employed to calculate deviations from Hardy-Weinberg equilibrium (HWE) and linkage disequilibrium (LD) between pairs of loci with Bonferroni's correction for multiple tests (Rice, 1989).

\section{RESULTS}

Twelve microsatellite loci were ultimately identified (Table 1). The number of al $\neg$ leles per locus ranged from 4 to 27 , with an average of 15.2. The mean $H_{\mathrm{O}}$ and $H_{\mathrm{E}}$ were 0.454 (range: $0.000-0.800$ ) and 0.673 (range: 0.097-0.910), respectively, for population $\mathrm{NC}$ and were 0.529 (range: $0.050-0.850$ ) and 0.735 (range: $0.309-0.931$ ), respectively, for popula $\neg$ tion JP. The PIC values were 0.637 (range: 0.090-0.878) and 0.694 (range: 0.2760.900 ) on average, for NC and JP respectively (Table 2). Most loci in the two populations deviated significantly from HWE expectations after Bonferroni's correction $(\mathrm{P}<0.004)$ due to an excess of heterozygotes. None of the loci showed significant LD.

\section{Table 1. Information of the twelve microsatellite loci developed for wild Brassica juncea.}

\begin{tabular}{|c|c|c|c|c|c|c|}
\hline Locus & Repeat motif & Primer sequence $\left(5^{\prime}-3^{\prime}\right)$ & Size (bp) & $\mathrm{Ta}\left({ }^{\circ} \mathrm{C}\right)$ & $N_{\mathrm{A}}$ & GenBank accession No. \\
\hline WBrajssr1 & $\begin{array}{l}\text { F: }(\mathrm{AC})_{6}(\mathrm{AG})_{5} \\
\text { R: CTTGAGGGGATATGACA }\end{array}$ & $\left.(\mathrm{AC})_{6} \mathrm{AG}\right)_{6}$ & 504 & 54 & 27 & JX144894 \\
\hline WBrajssr2 & $\begin{array}{l}\text { F: }(\mathrm{AC})_{6}(\mathrm{AG})_{5} \\
\text { R: AAGAGGGGTTCCTATGCT }\end{array}$ & $(\mathrm{AC})_{6}(\mathrm{AG})_{5}$ & 432 & 54 & 11 & JX144895 \\
\hline WBrajssr3 & $\begin{array}{l}\text { F: }(\mathrm{AC})_{6}(\mathrm{AG})_{5} \\
\text { R: GTAACCCTGCTGGTGATAGT }\end{array}$ & $(\mathrm{AC})_{6}(\mathrm{AG})_{5}$ & 133 & 54 & 17 & JX144896 \\
\hline WBrajssr4 & $\begin{array}{l}\text { F: }(\mathrm{AC})_{6}(\mathrm{AG})_{5} \\
\text { R: GAAGGTGACGTTGGAAG }\end{array}$ & $(\mathrm{AC})_{6}(\mathrm{AG})_{7}$ & 258 & 54 & 19 & JX144897 \\
\hline WBrajssr5 & $\begin{array}{l}\text { F: }(\mathrm{AC})_{6}(\mathrm{AG})_{5} \\
\text { R: GGAAGGTATTGGAAGC }\end{array}$ & $(\mathrm{AC})_{6}(\mathrm{AG})_{5}$ & 101 & 54 & 13 & JX144898 \\
\hline WBrajssr6 & $\begin{array}{l}\text { F: }(\mathrm{AC})_{6}(\mathrm{AG})_{5} \\
\text { R: CGAAACTCTTCTCCAA }\end{array}$ & $(\mathrm{AC})_{6}(\mathrm{AG})_{5}$ & 115 & 54 & 7 & JX144899 \\
\hline WBrajssr7 & $\begin{array}{l}\text { F: }(\mathrm{AC})_{6}(\mathrm{AG})_{5} \\
\text { R: ACGCAGCAACAACAAACC }\end{array}$ & $(\mathrm{AC})_{6}(\mathrm{AG})_{11}$ & 132 & 54 & 13 & JX144900 \\
\hline WBrajssr8 & $\begin{array}{l}\text { F: }(\mathrm{AC})_{6}(\mathrm{AG})_{5} \\
\text { R: ATCCTGCTGAGTTAGGTTTT }\end{array}$ & $(\mathrm{AC})_{6}(\mathrm{AG})_{6}$ & 259 & 54 & 16 & JX144901 \\
\hline WBrajssr9 & $\begin{array}{l}\text { F: }(\mathrm{AC})_{6}(\mathrm{AG})_{5} \\
\text { R: GGATTGAGAGAAAGAAGTC }\end{array}$ & $(\mathrm{AC})_{6}(\mathrm{AG})_{5}$ & 142 & 54 & 22 & JX144902 \\
\hline WBrajssr10 & $\begin{array}{l}\text { F: }(\mathrm{AC})_{6}(\mathrm{AG})_{5} \\
\text { R: AACGGCGGCGAGATGAAC }\end{array}$ & $(\mathrm{AC})_{6}(\mathrm{AG})_{15}$ & 116 & 54 & 18 & JX144903 \\
\hline WBrajssr11 & $\begin{array}{l}\text { F: }(\mathrm{AC})_{6}(\mathrm{AG})_{5} \\
\text { R: TTGACTTGGGAGATAACGA }\end{array}$ & $(\mathrm{AC})_{6}(\mathrm{AG})_{8}$ & 119 & 54 & 15 & JX144904 \\
\hline WBrajssr12 & $\begin{array}{l}\text { F: }(\mathrm{AC})_{6}(\mathrm{AG})_{5} \\
\text { R: AACTGCTAAGTGCGATGC }\end{array}$ & $(\mathrm{AC})_{6}(\mathrm{AG})_{5}$ & 109 & 54 & 4 & JX144905 \\
\hline
\end{tabular}

$\mathrm{Ta}=$ annealing temperature 
Table 2. Genetic diversity of the two populations of wild Brassica juncea.

\begin{tabular}{|c|c|c|c|c|c|c|c|c|c|c|}
\hline \multirow[t]{2}{*}{ Locus } & \multicolumn{5}{|c|}{$\mathrm{NC}(\mathrm{N}=20) 30^{\circ} 51^{\prime} \mathrm{N}, 106^{\circ} 04^{\prime} \mathrm{E}$} & \multicolumn{5}{|c|}{$\mathrm{JP}(\mathrm{N}=20) 32^{\circ} 00^{\prime} \mathrm{N}, 118^{\circ} 36^{\prime} \mathrm{E}$} \\
\hline & $N_{\mathrm{A}}$ & $H_{\mathrm{O}}$ & $H_{\mathrm{E}}$ & PIC & $\mathrm{P}_{\mathrm{HW}}$ & $N_{\mathrm{A}}$ & $H_{\mathrm{o}}$ & $H_{\mathrm{E}}$ & PIC & $\mathrm{P}_{\mathrm{HW}}$ \\
\hline WBrajssr1 & 15 & 0.600 & 0.672 & 0.645 & 0.219 & 18 & 0.750 & 0.929 & 0.900 & $0.000^{*}$ \\
\hline WBrajssr2 & 6 & 0.200 & 0.564 & 0.526 & $0.000^{*}$ & 8 & 0.100 & 0.622 & 0.581 & $0.000^{*}$ \\
\hline WBrajssr3 & 13 & 0.600 & 0.845 & 0.808 & $0.003 *$ & 10 & 0.800 & 0.744 & 0.684 & 0.160 \\
\hline WBrajssr4 & 11 & 0.700 & 0.759 & 0.709 & $0.000 *$ & 12 & 0.600 & 0.796 & 0.759 & $0.000^{*}$ \\
\hline WBrajssr5 & 8 & 0.300 & 0.754 & 0.697 & $0.000 *$ & 9 & 0.850 & 0.881 & 0.842 & $0.000^{*}$ \\
\hline WBrajssr6 & 4 & 0.250 & 0.388 & 0.354 & $0.003 *$ & 6 & 0.100 & 0.436 & 0.411 & $0.000^{*}$ \\
\hline WBrajssr7 & 9 & 0.800 & 0.709 & 0.660 & 0.228 & 7 & 0.850 & 0.660 & 0.583 & 0.259 \\
\hline WBrajssr8 & 8 & 0.500 & 0.586 & 0.541 & $0.001 *$ & 14 & 0.650 & 0.873 & 0.841 & $0.000^{*}$ \\
\hline WBrajssr9 & 14 & 0.100 & 0.910 & 0.878 & $0.000^{*}$ & 14 & 0.100 & 0.931 & 0.900 & $0.000^{*}$ \\
\hline WBrajssr10 & 12 & 0.750 & 0.903 & 0.868 & $0.000 *$ & 12 & 0.850 & 0.824 & 0.781 & 0.575 \\
\hline WBrajssr11 & 11 & 0.650 & 0.897 & 0.863 & $0.000 *$ & 9 & 0.650 & 0.819 & 0.775 & $0.000^{*}$ \\
\hline WBrajssr12 & 2 & 0.000 & 0.097 & 0.090 & 0.027 & 3 & 0.050 & 0.309 & 0.276 & $0.001 *$ \\
\hline
\end{tabular}

$\mathrm{N}=$ sample size for each population; $N_{\mathrm{A}}=$ number of alleles per locus; $H_{\mathrm{O}}=$ observed heterozygosity; $H_{\mathrm{E}}=$ expected heterozygosity; $\mathrm{PIC}=$ polymorphism information content; $\mathrm{P}_{\mathrm{HW}}=$ probability of deviation for Hardy-Weinberg proportions; *significant departures from Hardy-Weinberg equilibrium after Bonferroni's correction $(\mathrm{P}<0.004)$.

\section{DISCUSSION AND CONCLUSION}

We successfully developed SSR markers for wild B. juncea using the dual suppressionPCR method. All 12 loci showed high levels of polymorphism, indicating that the SSR markers are of great potential significance and profound influence for future research related to the genetic diversity and population structure of this species and for the elucidation of its evolutionary history.

\section{ACKNOWLEDGMENTS}

Research supported by the National Natural Science Foundation of China (\#31270579), the National R\&D Project of Transgenic Crops of Ministry of Science and Technology of China (\#2013ZX08011), and the Natural Science Foundation of Jiangsu Province (\#BK2010476).

\section{REFERENCES}

Clarke KR and Gorley RN (2001). Primer v5: User Manual/Tutorial. Primer-E Ltd., Plymouth.

Doyle JJ (1991). DNA Protocols for Plants. In: Molecular Techniques in Taxonomy (Hewitt GM, Johnston AWB and Young JPW, eds.). Springer-Verlag, Berlin, 283-293.

Huangfu CH, Song XL and Qiang S (2009). ISSR variation within and among wild Brassica juncea populations: implication for herbicide resistance evolution. Genet. Resour. Crop Evol. 56: 913-924.

Kalinowski ST, Taper ML and Marshall TC (2007). Revising how the computer program CERVUS accommodates genotyping error increases success in paternity assignment. Mol. Ecol. 16: 1099-1106.

Lian CL, Abdul WM, Geng Q, Shimatani K, et al. (2006). An improved technique for isolating codominant compound microsatellite markers. J. Plant Res. 119: 415-417.

Negi MS, Devic M, Delseny M and Lakshmikumaran M (2000). Identification of AFLP fragments linked to seed coat colour in Brassica juncea and conversion to a SCAR marker for rapid selection. Theor. Appl. Genet. 101: 146-152.

Pradhan AK, Gupta V, Mukhopadhyay A, Arumugam N, et al. (2003). A high-density linkage map in Brassica juncea (Indian mustard) using AFLP and RFLP markers. Theor. Appl. Genet. 106: 607-614.

Qiao AM, Liu PY and Lei JJ (1998). RAPD analysis of sixteen varieties of mustard. Act. Bot. Sin. 40: 915-921.

Rice WR (1989). Analyzing tables of statistical tests. Evolution 43: 223-225.

Tu HL and Qiu XL (1989). A Preliminary study on relationship between evolution model of wild Brassica juncea fields and the loss of wheat yield. Weed Sci. 3: 10-12. 